\title{
Оптимальний вибір варіанту розділення анатомічних компонентів черевної стінки при післяопераційних грижах живота великих та гігантських розмірів та профілактика ускладнень
}

\begin{abstract}
Мета роботи: оптимізувати вибір методики розділення анатомічних компонентів черевної стінки при післяопераційних грижах живота великих та гігантських розмірів.

Матеріали і методи. Проведено аналіз хірургічного лікування 215 пацієнтів з післяопераційними грижами живота (ПГЖ) великих та гігантських розмірів віком від 30 до 75 років (середній вік 54,7士3,3) за період з 2012 по 2019 рр. Жінок було 137 (63,7\%), чоловіків - 78 (36,3\%). Вибір варіанту CST у поєднанні з алопластикою при ПГЖ великих та гігантських розмірів виконували під час операції з урахуванням середніх показників ВЧТ при контактному зведенні прямих м’язів. Групу порівняння складали 82 пацієнти, яким в період з 2008 по 2011 рр. виконувалася ACST+onlay без врахування рівня ВЧТ.

Результати досліджень та їх обговорення. Оптимізація вибору варіанту CST при ПГЖ великих та гігантських розмірів може бути досягнута шляхом визначення ВЧТ під час операції при контактному зведенні прямих м’язів живота. Так, при ВЧТ $(5,4 \pm 2,1)$ мм рт. ст. $(0,7 \pm 0,3$ кПа) оптимальним варіантом $€$ ACST, при ВЧT $(9,1 \pm 2,3)$ мм рт. ст. $(1,2 \pm 2,3$ кПа) - PCST, при ВЧT $(14,1 \pm 2,3)$ мм рт. ст. $(1,9 \pm 0,3$ кПа) - TAR.

Використання диференційованого підходу до вибору варіанту CST у поєднанні з алопластикою при великих та гігантських ПГЖ з урахуванням ВЧТ сприяє покращенню результатів лікування, а саме зменшується частота АКС до 0,5 \% проти 4,9 \% у групі порівняння, сероми - до 15,8 \% проти 25,6 \%, інфікування післяопераційної рани - до 1,4 \% проти 4,9 \%, хронічного післяопераційного болю - до 4,2 \% проти 8,1%, рецидиву ПГЖ - до 1,4% проти 8,1%.
\end{abstract}

Ключові слова: післяопераційна грижа живота; методика розділення анатомічних компонентів; внутрішньочеревний тиск; алопластика.

Постановка проблеми і аналіз останніх досліджень та публікацій. Впровадження в хірургічне лікування післяопераційних гриж живота (ПГЖ) великих та гігантських розмірів методик розділення анатомічних компонентів черевної стінки (CST) у поєднанні з алопластикою значно покращило як безпосередні, так і віддалені результати лікування [1, 2]. Методики CST у поєднанні з алопластикою при ПГЖ великих та гігантських розмірів, з одного боку, забезпечують створення оптимального об’єму черевної порожнини та зменшують вірогідність виникнення абдомінального компартмент-синдрому (АКС), а 3 іншого - за рахунок максимального широкого перекриття м'язово-апоневротичних тканин черевної стінки сітчастим імплантатом зменшують ймовірність рецидивування ПГЖ [1, 3, 4, 5]. Водночас, частота виникнення АКС при гігантських ПГЖ навіть після виконання методик CST залишається досить високою $(4,8$ \%) $[1,4,6]$, а частота рецидивів ПГЖ утримується на рівні 10-15 \% $[1,7,8]$.

На наш погляд, диференційований підхід до вибору варіанту CST при ПГЖ гігантських розмірів з урахуванням показників внутрішньочеревного тиску (ВЧТ) при моделюванні герніопластики буде сприяти покращенню результатів лікування.
Мета роботи: оптимізувати вибір методики розділення анатомічних компонентів черевної стінки при післяопераційних грижах живота великих та гігантських розмірів.

Матеріали та методи. Проведено аналіз хірургічного лікування 215 пацієнтів з ПГЖ великих та гігантських розмірів віком від 30 до 75

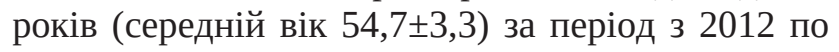
2019 рр. Жінок було 137 (63,7 \%), чоловіків - 78 (36,3 \%), без суттєвої різниці за окремими віковими групами $\left(\mathrm{X}^{2}=0,3 ; \pi=0,84\right)$.

Відповідно до класифікації Європейської асоціації хірургів-герніологів (EHS classification, Гент, Бельгія, 2008 р.) [9] ПГЖ великого та гігантського розміру розподілялись наступним чином: $\mathrm{M}_{1-4} \mathrm{~W}_{3} \mathrm{R}_{0}$ діагностовано у 67 (31,1\%), $\mathrm{M}_{1-4} \mathrm{~W}_{3} \mathrm{R}_{1}-$ y $16(7,4 \%), M_{1-5} W_{3} R_{0}-y 76(35,4 \%), M_{1-5}{ }_{1-4} \mathrm{~W}_{3} R_{1}-y$ $18(8,3 \%), \mathrm{M}_{4-5} \mathrm{~W}_{3} \mathrm{R}_{0}-\mathrm{y} 26(12,1 \%), \mathrm{M}_{4-5} \mathrm{~W}_{3} \mathrm{R}_{1}-\mathrm{y}$ 12 (5,5 \%). Рецидивні ПГЖ - у 46 (21,4\%) пацієнтів. Контрактура прямих м'язів живота спостерігалась у 192 (89,3 \%) пацієнтів. У 17 (7,9 \%) пацієнтів мала місце мацерація шкіри, виразка шкіри у 7 (3,2 \%), лігатурні нориці - у 8 (3,7 \%).

Серед супутніх захворювань: ішемічна хвороба серця, гіпертонічна хвороба II-III ст. спостерігалась у 119 (55,3 \%), хронічна спайкова хвороба 
органів черевної порожнини - у 132 (61,4 \%) пацієнтів, варикозна хвороба нижніх кінцівок - у 27 (12,6 \%), хронічний бронхіт - у 17 (7,9 \%), цукровий діабет - у 11 (5,1 \%), ожиріння II-III ст. - у 129 (60,0 \%).

Всім пацієнтам амбулаторно впродовж $(10,0 \pm 3,2)$ днів проводилася спеціальна передопераційна підготовка, яка включала: безшлакову дієту, дозовану бандажну компресію живота, дихальну гімнастику, корегуючу терапію супутніх захворювань.

Антибактеріальна профілактика проводилась 3 використанням цефалоспоринів III покоління за 2 години до операції. 3 метою профілактики тромбоемболічних ускладнень використовували клексан 40 мг підшкірно за 12 годин до операції та один раз на день після операції впродовж 7-9 днів, компресійну білизну для нижніх кінцівок під час операції та впродовж 1 міс. в післяопераційному періоді.

Вибір варіанту CST у поєднанні з алопластикою при ПГЖ великих та гігантських розмірів виконували під час операції з урахуванням середніх показників ВЧТ при контактному зведенні прямих м'язів.

ВЧТ вимірювали інтраопераційно через катетер Фолея (1 см водного стовпчика відповідає 0,735 мм рт. ст.) $[1,4,5]$.

Оптимальні показники ВЧТ для адекватного вибору CST були визначені ретроспективно шляхом моніторингу ВЧТ та оцінки результатів у попередньому дослідженні [10].

В I групі у 82 (38,1 \%) пацієнтів при моделюванні герніопластики шляхом контакного зведення прямих м'язів живота ВЧТ під час операції складав $(5,4 \pm 2,1)$ мм рт. ст. $(0,7 \pm 0,3$ кПа), виконувалась передня методика розділення анатомічних компонентів черевної стінки в поєднанні з алопластикою (ACST+sublay+onlay).

В II групі у 82 (38,1 \%) пацієнтів ВЧТ $(9,1 \pm 2,3)$ мм рт. ст. $(1,2 \pm 0,3$ кПа), задня методика розділення анатомічних компонентів черевної стінки в поєднанні з алопластикою (PCST+sublay).

В III групі у 51 (23,7\%) пацієнта ВЧТ -

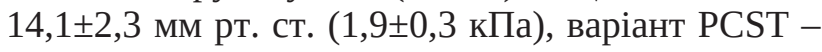
transversus abdominis muscle release в поєднанні 3 алопластикою (TAR+sublay).

Групу порівняння складали 82 пацієнти, яким в період з 2008 по 2011 рр. виконувалася ACST+onlay без врахування рівня ВЧТ.

В I групі пацієнтів виконувалася методика ACST за способом, розробленим в клініці [1]. Суть операції полягала в тому, що після висічення післяопераційного рубця виділяли та розрізали грижовий мі- шок. Зрощення в черевній порожнині роз'єднували, мобілізували апоневротичні краї грижового дефекту від підшкірної основи на ширину прямих м'язів живота. По краю піхви прямого м'яза живота розрізали апоневроз зовнішнього косого м'яза, мобілізували його від внутрішнього косого м'яза, що сприяло зміщенню прямого м’яза до серединної лінії в середньому на 6-8 см. Таку маніпуляцію виконували з обох боків. Після цього по краях дефекту розрізали піхви прямих м'язів, мобілізували ретром'язовий простір, поліпропіленовий сітчастий імплантат розміщували методикою “sublay”, а слабкі ділянки між піхвою прямого м'яза та апоневрозом зовнішнього косого м'яза живота укріплювали сітчастими імплантатами. Операцію завершували вакуумним дренуванням рани двома ПХВ дренажами та пошаровим її зшиванням.

PCST+sublay (II група пацієнтів). Виконували типову дисекцію ретром'язового простору шляхом розрізання апоневротичних піхв прямих м'язів живота. По внутрішніх краях прямих м'язів розрізали апоневроз внутрішнього косого м'яза живота та мобілізували косі м'язи від прямих та поперечних, що сприяло зміщенню прямих м'язів до білої лінії (серединної) в середньому на 10-12 см. Сітчастий імплантат відповідних розмірів розміщували та фіксували під прямими та косими м’язами (“sublay”).

Методика TAR, яка виконувалась у пацієнтів III групи, полягала в тому, що після виконання PCST, зокрема мобілізації поперечних м'язів, виконували їх розрізання та додаткову мобілізацію від внутрішніх косих м'язів, що збільшувало ширину черевної стінки на 14-15 см. Сітчастий імплантат відповідних розмірів розміщували ретромускулярно.

У ранньому післяопераційному періоді лікувальні заходи включали знеболення, корекцію водно-електролітного та білкового обмінів, корекцію порушень з боку серцево-судинної та дихальної систем, стимуляцію функції кишечника, антибактеріальну терапію, антикоагулянтну терапію.

Результати досліджень та їх обговорення. Оцінка результатів у I, II та III групах пацієнтів проводилась із врахуванням моніторингу ВЧТ, частоти загальних та місцевих ранових ускладнень, а також частоти хронічного післяопераційного болю та рецидивів у віддаленому післяопераційному періоді.

Показники моніторингу ВЧТ у I, II та III групах пацієнтів у передопераційному періоді, під час операції та у післяопераційному періоді наведені в таблиці. 
Таблиця. Показники внутрішньочеревного тиску при післяопераційних грижах живота великих та гігантських розмірів ( $\mathrm{n=215)}$

\begin{tabular}{|c|c|c|c|c|c|c|c|}
\hline Група & $\begin{array}{c}\text { Вихідний } \\
\text { рівень } \\
\text { ВЧТ } \\
\text { мм рт. ст. } \\
\text { (кПа) }\end{array}$ & $\begin{array}{c}\text { ВЧТ до } \\
\text { операції з } \\
\text { бандажною } \\
\text { компресією } \\
\text { мм рт. ст. } \\
\text { (кПа) }\end{array}$ & $\begin{array}{c}\text { ВЧТ під час } \\
\text { операції при } \\
\text { моделюванні } \\
\text { герніопластики } \\
\text { при зведенні } \\
\text { прямих м’язів } \\
\text { контактно, } \\
\text { мм рт. ст. (кПа) }\end{array}$ & $\begin{array}{c}\text { ВЧТ } \\
\text { безпосередньо } \\
\text { після операції, } \\
\text { мм рт. ст. } \\
\text { (кПа) }\end{array}$ & $\begin{array}{c}\text { ВЧТ через } \\
\text { 6-8 годин } \\
\text { після } \\
\text { операції, } \\
\text { мм рт. ст. } \\
\text { (кПа) }\end{array}$ & $\begin{array}{c}\text { ВЧТ через } 24 \\
\text { години після } \\
\text { операції, } \\
\text { мм рт. ст. } \\
\text { (кПа) }\end{array}$ & $\begin{array}{c}\text { ВЧТ через } \\
48 \text { годин } \\
\text { після } \\
\text { операції, } \\
\text { мм рт. ст. } \\
\text { (кПа) }\end{array}$ \\
\hline $\begin{array}{l}\mathrm{I} \\
(\mathrm{n}=82)\end{array}$ & $\begin{array}{c}0,6 \pm 0,2 \\
(0,1 \pm 0,02)\end{array}$ & $\begin{array}{c}4,7 \pm 1,3 \\
(0,6 \pm 0,2)\end{array}$ & $\begin{array}{c}5,4 \pm 2,1 \\
(0,7 \pm 0,3)\end{array}$ & $\begin{array}{c}5,7 \pm 1,2 \\
(0,8 \pm 0,2)\end{array}$ & $\begin{array}{c}6,9 \pm 1,4 \\
(0,9 \pm 0,2)\end{array}$ & $\begin{array}{c}5,6 \pm 1,3 \\
(0,7 \pm 0,2)\end{array}$ & $\begin{array}{c}5,4 \pm 2,1 \\
(0,7 \pm 0,3)\end{array}$ \\
\hline $\begin{array}{l}\text { II } \\
(n=82)\end{array}$ & $\begin{array}{c}0,8 \pm 0,2 \\
(0,1 \pm 0,02)\end{array}$ & $\begin{array}{c}5,1 \pm 1,2 \\
(0,7 \pm 0,2)\end{array}$ & $\begin{array}{c}9,1 \pm 2,3 \\
(1,2 \pm 0,3)\end{array}$ & $\begin{array}{c}5,3 \pm 1,2 \\
(1,7 \pm 0,2)\end{array}$ & $\begin{array}{c}6,7 \pm 1,3 \\
(0,9 \pm 0,2)\end{array}$ & $\begin{array}{c}5,2 \pm 1,2 \\
(0,7 \pm 0,2)\end{array}$ & $\begin{array}{c}5,1 \pm 1,6 \\
(0,7 \pm 0,2)\end{array}$ \\
\hline $\begin{array}{l}\text { III } \\
(n=51)\end{array}$ & $\begin{array}{c}0,9 \pm 0,2 \\
(0,1 \pm 0,02)\end{array}$ & $\begin{array}{c}5,2 \pm 2,1 \\
(0,7 \pm 0,3)\end{array}$ & $\begin{array}{c}14,1 \pm 2,3 \\
(1,9 \pm 0,3)\end{array}$ & $\begin{array}{c}5,1 \pm 1,2 \\
(0,7 \pm 0,2)\end{array}$ & $\begin{array}{c}6,4 \pm 1,3 \\
(0,9 \pm 0,2)\end{array}$ & $\begin{array}{c}5,1 \pm 1,2 \\
(0,7 \pm 0,2)\end{array}$ & $\begin{array}{c}4,9 \pm 1,2 \\
(0,7 \pm 0,2)\end{array}$ \\
\hline
\end{tabular}

За даними таблиці вихідний рівень ВЧТ у пацієнтів I, II та III груп, а такожпри бандажній компресії живота не перевищував норму і був порівняним. Під час виконання операції після переміщення органів із грижового мішка до черевної порожнини та при моделюванні герніопластики шляхом контактного зведення прямих м'язів у пацієнтів вимірювали ВЧТ, і залежно від його показників обирали методику розділення анатомічних компонентів передньої черевної стінки. До I групи ввійшли пацієнти, у яких ВЧТ складав $(5,4 \pm 2,1)$ мм рт. ст. $(0,7 \pm 0,3$ кПа), їм виконували ACST; до II групи - $(9,1 \pm 2,3)$ мм рт. ст. (1,2 $\pm 0,3$ кПа), PCST; до III групи - $(14,1 \pm 2,3)$ мм рт. ст. $(1,9 \pm 0,3$ кПа), TAR. Безпосередньо після операції спостерігались нормальні показники ВЧТ у всіх 3-х групах пацієнтів. Незначне підвищення ВЧТ спостерігалося через 6-8 годин після операції у всіх 3-х групах пацієнтів до $(6,9 \pm 1,4)$ мм рт. ст. $(0,9 \pm 0,2$ кПа) у пацієнтів I групи, $(6,7 \pm 1,3)$ мм рт. ст. $(0,9 \pm 0,2$ кПа) у пацієнтів II групи та $(6,4 \pm 1,3)$ мм рт. ст. $(0,9 \pm 0,2$ кПа) у пацієнтів III групи. Це пояснюється виникненням парезу кишечника. Активна стимуляція функції кишечника як механічна, так і медикаментозна, а також перидуральна анестезія сприяли відновленню пасажу та зниженню ВЧТ через 24 години після операції, але у 1 (1,2\%) пацієнта I групи зберігалася інтраабдомінальна гіпертензія $(12,0 \pm 1,4)$ мм рт. ст. $(1,6 \pm 0,2$ кПа) впродовж 24 годин, виник АКС I ступеня, який вдалося ліквідувати консервативними заходами. Через 48 годин після операції ВЧТ у всіх 3-х групах пацієнтів були в межах норми і були порівняними між собою. Це доводить той факт, що диференційований підхід до вибору методики розділення анатомічних компонентів передньої черевної стін- ки у пацієнтів з ПГЖ великих та гігантських розмірів шляхом вимірювання ВЧТ під час операції при моделюванні герніопластики при зведенні прямих м'язів є ефективним, на відміну від групи порівняння, в якій у 4 (4,9 \%) пацієнтів через 24 години після операції спостерігалась стійка інтраабдомінальна гіпертензія $(12,1 \pm 1,6)$ мм рт. ст.

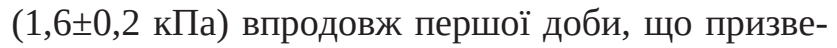
ло до виникнення АКС I ступеня. Цим пацієнтам проводилась пролонгована штучна вентиляція легень, перидуральна анестезія, назогастральна декомпресія шлунка, стимуляція функції кишечника (метоклопрамід, прозерин, гіпертонічні клізми), інфузійна терапія розчинами кристалоїдів та ін. Завдяки цим заходам відновився пасаж по кишечнику, ВЧТ знизився до $(8,1 \pm 2,1)$ мм рт. ст. $(1,1 \pm 0,3$ кПа) у $3(3,7 \%)$ пацієнтів, явища АКС були ліквідовані. 1 (1,2 \%) пацієнту консервативні заходи не допомогли, виконали декомпресійну релапаротомію. В II та III групах пацієнтів інтраабдомінальної гіпертензії та, відповідно АКС не спостерігалось.

Частота ускладнень з боку післяопераційної рани вивчалася та порівнювалася між собою у пацієнтів I, II та III груп. В I групі пацієнтів серома на ділянці післяопераційної рани спостерігалася у 21 (25,6 \%), інфікування післяопераційної рани - у 1 (1,2 \%), некроз шкірних країв рани - у 4 (4,9 \%), інфільтрат післяопераційної рани - у 11 (13,4 \%). В II групі пацієнтів: серома - у 7 (8,5 \%), інфікування післяопераційної рани - у 1 (1,2%), некроз шкірних країв рани - у 2 (2,4 \%), інфільтрат післяопераційної рани - у 4 (4,9%). В III групі пацієнтів: серома - у 6 (11,8 \%), інфікування післяопераційної рани - у 1 (1,9%), некроз шкірних країв рани - у 1 (2,0%), інфільтрат післяопе- 
раційної рани - у 2 (3,9 \%). Достовірно кращі результати спостерігались у пацієнтів II та III груп у порівнянні з I групою. Виникнення більш високої частоти місцевих ранових ускладнень у пацієнтів I групи було зумовлено більш широкою мобілізацією підшкірної основи від апоневротичних тканин, зокрема, за край розрізаного апоневрозу зовнішнього косого м'яза живота, що необхідно для оптимального перекриття сітчастим імплантатом. Крім цього, при методиці “onlay” велика площа контакту сітчастого імплантата з підшкірною основою. Широка мобілізація підшкірної основи від апоневротичних тканин та велика площа контакту сітчастого імплантата 3 підшкірною основою створює підгрунтя до виникнення сероми, інфікування, інфільтрату та некрозу шкірних країв післяопераційної рани.

Віддалені результати вивчені у 62 пацієнтів I групи, у 62 II групи, у 36 III групи та у 62 групи порівняння в строки від 1 до 5 років шляхом повторних оглядів та анкетування. Хронічний біль на ділянці черевної стінки впродовж 6-8 місяців після операції спостерігався у 1 (1,6 \%) пацієнтів I групи, у 5 (8,1 \%) II групи та у 3 (3,6 \%) III групи $(\mathrm{p}=0,094)$ і був ліквідований шляхом призначення фізіотерапевтичних процедур та нестероїдних протизапальних препаратів. Рецидиви грижі виявлені у 2 (3,2 \%) пацієнтів I групи та у 1 (2,8 \%) III групи ( $=0,352)$ через 8-12 місяців після операції, у пацієнтів II групи рецидивів грижі не спостерігалося. В групі порівняння хронічний біль виник у 5 (8,1 \%) пацієнтів, рецидив грижі - у 6 (9,7 \%).

Причиною виникнення рецидивів ПГЖ у пацієнтів I групи було інфікування післяопераційної рани, крайове відшарування та міграція сітчастого імплантату. Рецидив у пацієнта III групи виник по нижньому краю фіксації сітчастого імплантату в надлобковій області, з найбільшою вірогідністю, в результаті недостатнього перекриття сітчастим імплантатом нижнього краю дефекту черевної стінки.

\section{СПИСОК ЛІТЕРАТУРИ}

1. Післяопераційні грижі живота : монографія / Я. П. Фелештинський. - К. : ТОВ “Бізнес-Логіка”, - 2012. - 200 с.

2. Elzakaky N. Components separation technique in the management of large ventral hernias / N. Elzakaky, E. Elkayal, A. Shavky // Hernia. Abstract book. $1^{\text {st }}$ World conference on abdominal wall hernia surgery. - Milan, Italy. - 2015. - Vol. 19 (Suppl. 1). - P. 188.

3. Kenchadze G. Component separation technique in large incisional abdominal hernia repair: our experience / G. Kenchadze, I. Pipia, Z. Demetrashvili // Hernia. Abstract book. $1^{\text {st }}$ World conference on abdominal wall hernia surgery. - Milan, Italy. 2015. - Vol. 19 (Suppl. 1). - P. 187.

4. Novitsky W. Y. Hernia surgery / W. Y. Novitsky. - Springer
Провели порівняння результатів лікування всіх 215 пацієнтів I, II, III групи та 82 пацієнтів групи порівняння. Виявили, що використання диференціального підходу до вибору варіанту CST у поєднанні з алопластикою при великих та гігантських ПГЖ з урахуванням ВЧТ сприяє покращенню результатів лікування, а саме зменшується частота АКС до 0,5 \% проти 4,9 \% у групі порівняння, сероми - до 15,8 \% проти 25,6 \%, інфікування післяопераційної рани - до 1,4 \% проти 4,9%, хронічного післяопераційного болю - до 4,2 \% проти 8,1 \%, рецидиву ПГЖ - до 1,4 \% проти 8,1 \%.

Диференційований підхід до вибору методики розділення анатомічних компонентів передньої черевної стінки у пацієнтів з ПГЖ великих та гігантських розмірів шляхом вимірювання ВЧТ під час операції при моделюванні герніопластики при зведенні прямих м'язів живота є ефективним, дозволяє попередити виникнення інтраабдомінальної гіпертензії шляхом створення оптимального об’єму черевної порожнини.

Висновки. Оптимізація вибору варіанту CST при ПГЖ великих та гігантських розмірів може бути досягнута шляхом визначення ВЧТ під час операції при контактному зведенні прямих м'язів живота. Так, при ВЧТ $(5,4 \pm 2,1)$ мм рт. ст. $(0,7 \pm 0,3$ кПа) оптимальним варіантом $€$ ACST, при ВЧТ $(9,1 \pm 2,3)$ мм рт. ст. $(1,2 \pm 2,3$ кПа) - PCST, при ВЧТ $(14,1 \pm 2,3)$ мм рт. ст. $(1,9 \pm 0,3$ кПа) - TAR.

Використання диференційованого підходу до вибору варіанту CST у поєднанні з алопластикою при великих та гігантських ПГЖ з урахуванням ВЧТ сприяє покращенню результатів лікування, а саме зменшується частота АКС до 0,5 \% проти 4,9 \% у групі порівняння, сероми - до 15,8 \% проти 25,6 \%, інфікування післяопераційної рани - до $1,4 \%$ проти 4,9 \%, хронічного післяопераційного болю - до 4,2 \% проти 8,1 \%, рецидиву ПГЖ - до $1,4 \%$ проти $8,1 \%$.

International Publishing Switzerland. - 2016. - 530 p.

5. Schumpelick V. Reccurent hernia. Prevention and treatment / V. Schumpelick, R. J. Fitzgibbons. - Springer-Verlag. Berlin. Heidelberg, 2007. - 433 p.

6. Abdominal compartment syndrome / P. Bertram, A. Schachtrupp, R. Rosch, V. Schumpelick // Chirurg. - 2006. No. 77. - P. 573-v579.

7. LeBlanc A. K. Management of abdominal hernias (Fifth edition) / A. K. LeBlanc, A. Kingsnorth, L. D. Sanders. - Springer International Publishing. - 2018. - 541 p.

8. Millbourn D. Risk factors for wound complications in midline abdominal incisions related to the size of stitches / D. Millbourn, Y. Cengiz, L. A. Israelsson // Hernia. - 2011. - Vol. 15. - P. 261-266. 
9. Classification of primary and incisional abdominal wall hernias / F. E. Muysoms, M. Miserez, F. Berrevoet [et al.] // Hernia. - 2009. - Vol. 13 (4). - P. 407-414.

10. Intraperitoneal alloplasty combined with the anterior separation technique in giant incisional hernias / O. Lerchuk, I. P. Feleshtynskyi, V. V. Smishchuk [et al.] // Polski Przeglad Chirurgiczny. - 2018. - Vol. 91 (1). - P. 1-5. DOI: $10.5604 / 01.3001 .0012 .7798$.

\section{REFERENCES}

1. Feleshtynskyi, Ya.P. (2012). Pisliaoperatsiini hryzhi zhyvota: Monohrafiia [Incisional abdominal hernia: Monography]. Kyiv: TOV "Biznes-Lohika” [in Ukrainian].

2. Elzakaky, N., Elkayal, E., Shavky, A. (2015). Components separation technique in the management of large ventral hernias. Hernia. Abstract book. $1^{\text {st }}$ World conference on abdominal wall hernia surgery. Milan, Italy.

3. Kenchadze, G., Pipia, I., \& Demetrashvili, Z. (2015). Component separation technique in large incisional abdominal hernia repair: our experience. Hernia. Abstract book. $1^{\text {st }}$ World conference on abdominal wall hernia surgery. Milan, Italy.

4. Novitsky, W.Y.(2016). Hernia surgery. Springer International Publishing Switzerland.

5. Schumpelick, V., \& Fitzgibbons, R.J. (2007). Reccurent hernia. Prevention and treatment. Springer-Verlag. Berlin. Heidelberg.

6. Bertram, P., Schachtrupp, A., Rosch, R., \& Schumpelick, V. (2006). Abdominal compartment syndrome. Chirurg., 77, 573-579. 7. LeBlanc, A.K., Kingsnorth, A., \& Sanders, L.D. (2018). Management of abdominal hernias (Fifth edition). Springer International Publishing.

8. Millbourn, D., Cengiz, Y., \& Israelsson, L.A. (2011). Risk factors for wound complications in midline abdominal incisions related to the size of stitches. Hernia, 15, 261-266.

9. Muysoms, F.E., Miserez, M., \& Berrevoet, F. (2009). Classification of primary and incisional abdominal wall hernias. Hernia, 13 (4), 407-414.

10. Lerchuk, O., Feleshtynskyi, I.P., Smishchuk, V.V., Vatamaniuk, V.F., \& Svyrydovskyi, S.A. (2018). Intraperitoneal alloplasty combined with the anterior separation technique in giant incisional hernias. Polski Przeglad Chirurgiczny, 91 (1), 1-5. DOI: 10.5604/01.3001.0012.7798.

Отримано 29.11.2019

Електронна адреса для листування: feleshtynsky@yahoo.com

\section{YA. P. FELESHTYNSKY, V. V. SMISHCHUK, O. S. MARSHTUPA, V. F. VATAMANIUK, S. A. SVYRYDOVSKY}

P. Shupyk National Medical Academy of Postgraduate Education, Kyiv

\section{OPTIMAL CHOICE OF COMPONENT SEPARATION TECHNIQUE FOR LARGE AND GIANT INCISIONAL HERNIAS AND PREVENTION OF COMPLICATIONS}

The aim of the work: to optimize the choice of the method of component separation technique of the abdominal wall in case of large and giant incisional abdominal hernias.

Materials and Methods. The analysis of surgical treatment of 215 patients with large and gigantic incisional hernias of age from 30 to 75 years (mean age $(54.7 \pm 3.3)$ ) for the period from 2012 to 2019 was conducted. There were 137 women (63.7 \%), 78 (36.3\%) men. The choice of the component separation technique (CST) in combination with alloplasty for large and gigantic incisional hernias was performed during surgery with monitoring intraabdominal pressure (IAP) when contacting the abdominal muscles. The comparison group consisted of 82 patients who underwent ACST+onlay between 2008 and 2011 without monitoring IAP.

Results and Discussion. Optimization of the choice of the CST option for large and gigantic incisional hernias can be achieved by monitoring IAP when contacting the abdominal muscles. Thus, at an IAP of $(5.4 \pm 2.1) \mathrm{mm} \mathrm{Hg}(0.7 \pm 0.3) \mathrm{kPa}$ ACST is the best option, at $(9.1 \pm 2.3) \mathrm{mm} \mathrm{Hg} .(1.2 \pm 2.3) \mathrm{kPa}-$ PCST, at $(14.1 \pm 2.3) \mathrm{mm} \mathrm{Hg}(1.9 \pm 0.3) \mathrm{kPa}-\mathrm{TAR}$.

The use of a differential approach to the choice of the CST option in combination with alloplasty for large and gigantic incisional hernias with monitoring IAP contributes to the improvement of treatment results, namely decreasing the rate of abdominal compartmet syndrome to $0.5 \%$ versus $4.9 \%$ in the comparison group, seroma - to $15.8 \%$ versus $25.6 \%$, infection of the postoperative wound - to $1.4 \%$ versus $4.9 \%$, chronic postoperative pain - to $4.2 \%$ versus $8.1 \%$, recurrence of hernia - to $1.4 \%$ versus $8.1 \%$.

Key words: incisional hernia; component separation technigue; intraabdominal pressure; alloplasty. 


\author{
Я. П. ФЕЛЕШТИНСКИЙ, В. В. СМИЩУК, А. С. МАРШТУПА, В. Ф. ВАТАМАНЮК, С. А. СВИРИДОВСКИЙ
}

Национальная медицинская академия последипломного образования имени П. Л. Шупика, Киев

\title{
ОПТИМАЛЬНЫЙ ВЫБОР ВАРИАНТА РАЗДЕЛЕНИЯ АНАТОМИЧЕСКИХ КОМПОНЕНТОВ БРЮШНОЙ СТЕНКИ ПРИ ПОСЛЕОПЕРАЦИОННЫХ ГРЫЖАХ ЖИВОТА БОЛЫШИХ И ГИГАНТСКИХ РАЗМЕРОВ И ПРОФИЛАКТИКА ОС.ЛОЖНЕНИЙ
}

Цель работы: оптимизировать выбор методики разделения анатомических компонентов брюшной стенки при послеоперационных грыжах живота крупных и гигантских размеров.

Материалы и методы. Проведен анализ хирургического лечения 215 пациентов с послеоперационными грыжами живота (ПГЖ) крупных и гигантских размеров в возрасте от 30 до 75 лет (средний возраст 54,7 \pm 3,3) за период с 2012 по 2019 года. Женщин было 137 (63,7 \%), мужчин - 78 (36,3 \%). Выбор варианта разделения анатомических компонентов брюшной стенки (CST) в сочетании с аллопластикой при ПГЖ крупных и гигантских размеров выполняли во время операции с учетом средних показателей внутрибрюшного давления (ВБД) при контактном сведении прямых мышц. Группу сравнения составили 82 пациентов, которым в период с 2008 по 2011 года выполнялась передняя CST+onlay без учета уровня ВБД.

Результаты исследований и их обсуждение. Оптимизация выбора варианта CST при ПГЖ крупных и гигантских размеров может быть достигнута путем определения ВБД во время операции при контактном сведении прямых мышц живота. Так, при ВБД $(5,4 \pm 2,1)$ мм рт. ст. $(0,7 \pm 0,3$ кПа) оптимальным вариантом является ACST, при ВБД $(9,1 \pm 2,3)$ мм рт. ст. $(1,2 \pm 2,3$ кПа) PCST, при ВБД $(14,1 \pm 2,3)$ мм рт. ст. $(1,9 \pm 0,3$ кПа) - TAR.

Использование дифференциального подхода к выбору варианта CST в сочетании с аллопластикой при больших и гигантских ПГЖ с учетом ВБД способствует улучшению результатов лечения, а именно уменьшается частота АКС до 0,5 \% против 4,9 \% в группе сравнения, серомы - до 15,8 \% против 25,6 \%, инфицирования послеоперационной раны - до 1,4 \% против 4,9 \%, хронического послеоперационной боли - до 4,2 \% против 8,1%, рецидива ПГЖ - до 1,4 \% против 8,1%.

Ключевые слова: послеоперационная грыжа живота; методика разделения анатомических компонентов; внутрибрюшное давление; аллопластика. 